\section{Can the Chinese Two-Tier-Board System Control the Board Chair Pay?}

\author{
Shujun Ding \\ Accounting Area, School of Administrative Studies \\ Faculty of Liberal Arts \& Professional Studies, York University \\ 4700 Keele St., Toronto, Ontario M3J 1P3, Canada
}

Tel: 1-416-736-2100 ext 20873 E-mail: sjding@yorku.ca

Zhenyu Wu (Corresponding author)

Department of Finance and Management Science

Edwards School of Business, University of Saskatchewan

25 Campus Drive, Saskatoon, Saskatchewan S7N 5A7 Canada

Tel: 1-306-966-7779 E-mail: wu@edwards.usask.ca

\section{Yuanshun Li}

Finance Department, Ted Rogers School of Business Management, Ryerson University 350 Victoria St., Toronto, Ontario M5B 2K3, Canada

Tel: 1-416-979-5000 ext 6711 E-mail: yuli@ ryerson.ca

\begin{abstract}
Chunxin Jia
Department of Finance, Guanghua School of Management, Peking University

Beijing 100871, China
\end{abstract}

Tel: 86-10-6275-7795 E-mail: cjia@gsm.pku.edu.cn

\begin{abstract}
Monitoring function of the Chinese two-tier-board system is expected to affect firms' executive compensation in two ways: (i) improve firm performance which is considered as a partial basis of executive compensation (ii) monitor executives' behaviors to avoid over-pay. This article investigates if corporate governance mechanism indeed benefits in these two ways from major
\end{abstract}


characteristics of supervisory boards, one of the two monitoring organs in Chinese publicly listed companies. We find that supervisory board size is negatively related to the board chair pay, presumably because the monitoring effects of the size of supervisory board on board chair's behaviors dominate those on firm performance. We also find a high level of board chair pay-supervisory board sensitivity in the Chinese publicly listed companies.

\section{JEL Classifications: G34, G39}

Keywords: Board chair pay; Monitoring; Corporate governance

\section{Introduction}

Mr. Levitt, the former Chairman of SEC, commented that "if there is anything that engages the public today about the business community, it is the issue of compensation" (Levitt, 2005, p. 41). In the corporate governance literature, executive compensation has also received dramatic attention (e.g., Nager, 2002; Dutta, 2003; Lin, 2005; Ortiz-Molina, 2007; Balsam and Miharjo, 2007), and some pioneer studies have investigated compensation-related issues from an ethical perspective (e.g., Perel, 2003; Ashely and Yang, 2004; Matsumura and Shin, 2005; Mahoney and Thom, 2006; Persons, 2006). In both mature and emerging markets, for instance, pay-performance relationship is considered critical for providing appropriate incentives for executives, and this issue has been extensively examined by academics (e.g. Jensen and Murphy, 1990; Nichols and Subramaniam, 2001; Firth, Fung, and Rui, 2006; Cordeiro, Veliyath and Romal, 2007; Angel and McCable, 2008). Unfortunately, the results are mixed although some show a significant pay-performance relationship (e.g., Elston and Goldberg, 2003; Jensen and Murphy, 1990; Firth et al., 2006), which either has a low explanatory power or is not supported by other studies.

The inconsistent pay-performance link, as well as the low pay-performance sensitivity, suggests that other factors may have contributed to the executive compensation level. Among these factors, corporate governance mechanisms, especially board of directors and ownership structure, have been found to be some of the significant determinants of executive compensation (e.g. Boyd, 1994; Ryan and Wiggins, 2004). Boyd (1994), for example, finds that CEO's compensation is significantly higher in firms with a lower level of board control. These studies fall into the field of monitoring which is one of the useful tools for lowering agency costs. Our study continues this stream of research by examining the monitoring effects of another corporate governance organ, the supervisory board, on board chair pay in China. To our best knowledge, this is the first study which investigates the board chair pay-supervisory board relationship. Furthermore, prior studies examining executive compensation focus on mature markets, and the determinants of executive compensation in emerging markets are understudied (Ramaswamy, Veliyath, and Gomes, 2000). Our study is intended to fill this gap from the perspective of corporate governance. 
Two of the most effective corporate governance mechanisms in the world are the Anglo-American governance system and the German two-tier board system, and supervisory board is one of the typical features of the latter one. Both mechanisms have been codified into the Chinese Corporate Law since 1993 in a way similar to the Japanese mechanism. However, the supervisory boards in China are designed loosely on the German model, and their major duties lie in monitoring the executives and the board of directors. Therefore, the Chinese governance mechanism is more likely a combination of the U.S., German and Japanese systems. According to the amended Corporate Law effective on January 1, 2006, the board of directors in a Chinese publicly listed company is responsible for its daily operation, while supervisory boards monitor the behaviors of the board and the management team. Furthermore, supervisory boards are required to examine the financial affairs of the company. As board chairs in many of the Chinese publicly listed companies also serve as the CEOs, it is even more important to have the supervisory board to monitor their behaviors ${ }^{1}$.

As stated in the China Corporate Governance Survey published by the CFA Institute, the monitoring functions of supervisory board in Chinese publicly listed companies have been further clarified and strengthened by the revised version of the Corporate Law. Wang (2005) also confirms this improvement of supervisory board's legal power and monitoring functions. These findings are in sharp contrast to the conventional wisdom that supervisory boards are just a decoration to the Chinese corporate governance system $(\mathrm{Xi}, 2006)$ and prior findings that they play very little role in publicly listed companies in China (e.g. Dahya, Karbhari, Xiao, and Yang, 2003). Using data in 2005 and 2006 from the two stock markets in China, we examine the research questions using the meeting frequency and size of a supervisory board as proxies for its activities and characteristics, and show that supervisory boards influence board chair pay significantly. Comparing with the conclusions made by prior research, therefore, we show the improvement of the legal and investment environment in China in recent years. Therefore, our findings are able to provide important policy implications to authorities in China and other jurisdictions who are eager to improve the efficiency of corporate governance, and are of interest and of importance to better understand economic integration.

As supervisory board serves as one of the two monitoring organs in the Chinese two-tier-board corporate governance mechanism but its role has not been extensively examined, this study focuses on how the two-tier-board system affects the board chair pay in order to highlight part of its functionalities in Chinese publicly listed companies. As mentioned before, board of directors is in charge of daily operations, while supervisory board monitors behaviors of both board of directors and the management team. Therefore, examining the role played by a supervisory board in controlling the board chair pay in Chinese markets contributes to the literature in several ways. First, as far as we are aware, this study is among the first to shed light on whether and, if yes, how supervisory boards influence board chair pay and the effectiveness of corporate governance mechanisms. Second, with the dramatically increasing popularity of globalization and economic integration, it may provide developing nations with implications

\footnotetext{
${ }^{1}$ Note that according to the Chinese Corporate Law, members serving on the board of directors and top management are not allowed to serve on the supervisory board.
} 
about effective corporate governance mechanisms by analyzing the unfolding governance reform in China. Third, results presented in the current study have crucial implications for government policies and regulations. The Corporate Law in China, an important objective of which is to better integrate the Anglo-American style corporate governance mechanism and the German system, was newly amended in 2005. Results of our study highlight the improvement of legal environment and investor protection in China, and illustrate the legal approach in a more vivid way. The valuable experience and/or lessons from this process are instructive for other jurisdictions, especially emerging markets, to develop or refine their governance systems. Fourth, it adds to the corporate governance literature methodologically by separating the indirect from direct effects of the size of supervisory board on board chair pay, and contributes to the compensation literature from an ethical perspective.

The article is organized as follows. In section 2, we review the literature, discuss the background for the study, and list our hypotheses. Data and methodology are introduced in section 3 , followed by section 4 which presents and discusses the results. Conclusions are made in section 5 .

\section{Literature Review and Theoretical Background}

In the past 75-80 years, pay-performance relationship has been one of the mainstream issues investigated by academic researchers in various fields of management. Unfortunately, however, there is no final say about this relationship in the relevant literature. A seminal study in this field, Jensen and Murphy (1990), finds an increase in the CEO compensation of $\$ 3.25$ on average per $\$ 1,000$ increase in shareholders' wealth, but the pay-performance sensitivity is considered very low. Recent studies, such as Hall and Liebman (1998), Aggarwal and Samwick (1999, 2003), Fosberg (2001), and Elston and Goldberg (2003), find higher pay-performance sensitivities using more recent data, but empirical findings reported are still mixed.

A new stream of research in the more recent literature focuses on the influence of corporate governance on issues about executive compensation (e.g., Nager, 2002; Dutta, 2003; Lin, 2005; Ortiz-Molina, 2007; Balsam and Miharjo, 2007), and studies have done so by comparing public with private firms (e.g., Ke, Petroni and Safieddine, 1999), by emphasizing on specific ownership structures (e.g., Boyd, 1994; Kraft and Niederprum, 1999; Hartzell and Starks, 2003), and by taking into account investor protection (e.g., La Porta, Lopez-de Silanes, Shleifer, and Vishny, 2000; Ryan and Wiggins, 2004). These studies shed light on this critical corporate governance issue from different aspects. Most of their findings are summarized by a survey paper written by Devers, Cannella, Reilly, and Yoder (2007), who also address other recent developments in the literature on executive compensation.

With the increasingly important role played by emerging markets, a new trend in the corporate governance literature has appeared, and it is to analyze the executive compensation issues in unique corporate governance mechanisms adopted by them. Typical examples include Yueh (2004), Chen, Firth, Gao and Rui (2006), Firth, et al. (2006), and Kato and Long (2006), and these studies significantly add to the literature on corporate governance-executive compensation relationship in China, one of the most fast-growing emerging markets in the 
global economy in recent years. With the efforts made by various parties including the Chinese government, the Chinese market has been one of the largest public stock markets in the world, and it became the largest one in term of IPO proceeds. The fast growth of the Chinese market has attracted the attention of both international investors and academic researchers, and therefore, corporate governance and investor protection issues have been the popular topics to address.

The co-existence of board of directors and supervisory boards has been in place since the very beginning of Chinese markets. This system has been stable until the beginning of the new millennium; at that time, listed companies are mandatorily required to implement independent directorships. But supervisory boards remain as one of the two monitoring organs. Evidence on the role of supervisory boards is mixed. For example, Xiao, Dahya and Lin (2004) found that supervisory boards rarely serve as an independent watchdog; rather, they are more likely to be honored guests and friendly advisors. Dahya et al. (2003), however, provide interesting evidence regarding the role of supervisory boards; the market reacted negatively when a company failed to include the report of supervisory boards in its annual report. A recent study by Firth, Fung, and Rui (2007) shows that the two-tier board does play a role, as both significantly positively affect the informativeness of earnings. Despite the mixed evidence, people generally perceive supervisory boards as dysfunctional. Our study thus is able to shed light on this important issue by employing more recent data, and contributes to the ongoing debate whether the dual-board structure is functioning as expected.

It is widely accepted that Chinese legal and investment environment has been dramatically improved in the past 15 years since early 1990s. Whereas China started the economic transition in late 1970s, corporate governance and investor protection have not been clearly specified until the establishment of the two stock markets at the beginning of 1990s. In 1993, the first version of Corporate Law was enacted, and it underwent three major amendments within 15 years after that. The most recent one was done in 2005, and it became effective on January 1, 2006. The Corporate Law clearly states that China adopts a unique dual-board corporate governance system involving both board of directors and supervisory board. This is similar to the Japanese and German two-tier-board systems, but it combines the major features of the German, Japanese and the U.S. systems. In the Chinese unique corporate governance system, supervisory board is not responsible for daily operations of the company, but serves as one of the two monitoring organs, together with the independent directors who are part of the board of directors in the U.S. system.

Most of the prior research has concluded that, while board of directors plays an important role in the Chinese dual-board governance system, supervisory board is dysfunctional (Xiao et al., 2004; Xi, 2006). However, this situation has been dramatically changed with the newly amended Corporate Law being effective in 2006. According to this new version, members on the supervisory board are mainly responsible for monitoring the behaviors of top management team and members on the board of directors, and they are required and legally supported to examine the financial affairs of the company. Using the information up to date, Firth, et al. 
(2007) find that supervisory boards significantly increase earnings informativeness. Using more recent data from 2001 to 2006, Wu, Li, Ding, and Jia (2009) show the significant monitoring effects of supervisory board on financial leverage of Chinese publicly listed companies. However, the functionality of supervisory board in the Chinese unique corporate governance system is still undetermined.

Another unanswered question is about the corporate governance-executive compensation relationship in Chinese publicly listed companies. Firth et al. (2006) find a significant pay-performance relation for two ownership structures in China. Kato and Long (2006) even report that the pay-performance sensitivity in China is higher than that in the U.S. using more up-to-date information. To add to this literature, one needs to look back at the executive compensation reform during the economic transition in China within the past 30 years. As well known, most of the publicly listed companies whose stocks are traded in the two stock markets in China were converted from state-owned enterprises, and therefore the compensation was highly restricted by the government at the early stage. This situation was gradually changed since mid-1980s, but not fundamentally until 1994 (Mengistae and Xu, 2004; Yueh, 2004; Firth et al., 2006; Kato and Long, 2006). Starting 1994, these companies were allowed to set up their own compensation form with both fixed salary and performance-related pay for executives (Liu and Otsuka, 2004; Kato and Long, 2006), and doing so moved the Chinese corporate governance system closer to the German and the U.S. ones.

Instead of looking at the pay-performance relationship in Chinese publicly held companies, therefore, we focus on the influences of supervisory boards on the board chair pay. Doing so allows us to help answer the two undetermined questions mentioned above, the effectiveness of supervisory board and the effects of corporate governance on board chair pay. Thus, the major hypothesis of the current study is that supervisory board monitors the board chair pay effectively. There are two possible ways for supervisory board to affect the board chair pay; the first is to increase the board chair pay through enhancing the firm performance which is a partial basis of the board chair pay, and the second is to decrease the board chair pay by monitoring board chairs' behaviors to stop them from overpaying themselves.

According to the above review of the literature and the discussion about the theoretical background of this study, we have the following two hypotheses:

Hypothesis 1: Supervisory board meeting frequency in Chinese publicly listed companies decreases the board chair pay.

Hypothesis 2: Size of supervisory board in Chinese publicly listed companies decreases the board chair pay.

By testing the above two hypotheses, we highlight the effects of activities and characteristics of supervisory board on board chair pay. In the rich corporate governance literature, meeting frequency has been widely used as a proxy for board activities (e.g., Vafeas, 1999), and board size has also been extensively chosen to measure board characteristics when agency issues are 
addressed (e.g., Jensen, 1993). Previous studies also indicate that meeting frequency may be affected by past firm performance (Vafeas, 1999), and that size may have a significant influence on efficiency of board activities (Jensen, 1993). As research on monitoring effects of supervisory board in Chinese publicly listed companies is rare, we follow the broad corporate governance literature to use supervisory board meeting frequency and supervisory board size to measure its activities and characteristics, respectively ${ }^{2}$.

\section{Data, Variables, Models, and Estimation}

\subsection{Data}

To answer the research questions raised above and to test the hypothesis, we adopt data of Chinese publicly listed companies in the two Chinese markets, the Shanghai Stock Exchange and the Shenzhen Stock Exchange, in 2005 and 2006. One of the major reasons to choose data in these two years is the availability of the information about individual executive's compensation. This information before 2005 is not available because disclosing individual information was not mandatory until that year. We extract data from the data sets published by two major financial market data collection companies in China, the GTA and SINOFIN, whose products have been employed by prior studies such as Sun and Tong (2003), Bai, Liu, Lu, Song, and Zhang (2004), Wei, Xie and Zhang (2005), Haw, Qi, Wu and Wu (2005), Kato and Long (2006), and Jia (2009). There are 1,345 observations from Year 2005 and 1,410 from Year 2006.

To ensure the quality of the study, we cross-checked the accuracy of the information carried by the two data sets. Whenever we found inconsistency between them, we manually checked the information disclosed in the original annual reports published on the websites of the Shanghai Stock Exchange and the ShenZhen Stock Exchange, and kept the correct information.

\subsection{Variables}

This study is to investigate the effects of supervisory board on board chair pay. Prior research (e.g., Firth, Fung, and Rui, 2006) focuses on the CEO compensation since it is widely accepted that $\mathrm{CEO}$ is the one who makes major decisions in a company. In China, however, the situation is different since the chairman of board of directors is the actual leader of a company (Chen, et al., 2006). According to the Corporate Law first promulgated in 1993, the chairman of board of directors, instead of the CEO, is the legal representative of the public company. In addition, since most of listed firms in China were reorganized from SOEs, the Chinese government is involved in firm management more often than dominating shareholders in corporations in mature markets. Pistor and $\mathrm{Xu}$ (2005) find that administrative governance is more important than legal governance in China's financial markets. The administrative governance extends to publicly listed companies mainly through the board chair, who usually comes from the government or SOEs. As discussed in the introduction section, in addition, board chairs in many of the listed companies in China are also their CEOs, and represent the benefits of both shareholders and management teams. Among the rich literature on CEO compensation, the

\footnotetext{
${ }^{2}$ Note that as the newly-amended Corporate Law is expected to improve the effectiveness of the dual-board corporate governance mechanism in Chinese publicly listed companies, supervisory board's functionality has been improved, and therefore we hypothesize that its activities and characteristics may help curb board chair pay.
} 
monitoring effects of independent directors on CEO compensation have been considered using U.S. listed companies with CEO as the board chair (e.g., Core, Holthausen, and Larcker, 1999; Anderson and Bizjak, 2003; Chhaochharia and Grinstein, 2008; Guedj and Barnea, 2009) ${ }^{3}$. Since supervisory board serves as one of the monitoring organs in Chinese listed companies and is required to monitor behaviors of both board of directors and management team, it is of importance to investigate the effects of activities and characteristics of a supervisory board on board chair's compensation. Therefore, we make use of the executive pay received by the board chair (BCpay) as the dependent variable ${ }^{4}$.

While research on the monitoring effects of supervisory board is rare, there is a rich literature on functions of board of directors, and therefore, we follow previous researchers (Jensen, 1993; Vafeas, 1999; Jia, Ding, Li, Wu, 2009; Wu, et al., 2009) and measure characteristics of supervisory board using three variables. They are the meeting frequency of supervisory board (SBMF), its size (SBS), and the turnover of its chairman (SBCTurnover), and they serve as the independent variables in this study. While SBMF and SBS are continuous variables, SBCTurnover is a binary variable indicating whether there is a turnover of the chairman of the supervisory board in a year.

While studying the monitoring effects of board meeting frequency on firm performance, Vafeas (1999) indicates that a firm's board meeting frequency may be influenced by lagged firm performance and its risk-taking behaviors in the past year. Under the agency theory (Jensen, 1993), one also realizes that the size of supervisory board can also influence its meeting frequency. In other words, a supervisory board with a larger size tends to meet more to reach agreements. In the current study, the research objective is to investigate the monitoring effects of the activities and characteristics of supervisory board on board chair pay in Chinese publicly listed companies. We have also mentioned before that supervisory board is responsible for monitoring behaviors of board of directors and management team. Therefore, the potential influence of past performance and risk-taking behaviors on supervisory board meeting frequency needs to be considered. Thus, we follow and further develop the method proposed in Vafeas (1999) to separate the monitoring-induced supervisory board meeting frequency (MISBMF) from the performance-and-risk-induced component using the following model:

$$
S B M F_{\text {current }}=f\left(F P_{\text {past }}, \text { Risk }_{\text {past }}, S B S_{\text {current }}, \text { IBSize, SBCTurnover, control var iables }\right)+\varepsilon_{1}
$$

where the subscript "current" indicates variables in the current years and the subscript "past" indicates those in the past year. The variable IBSize indicates the number of independent

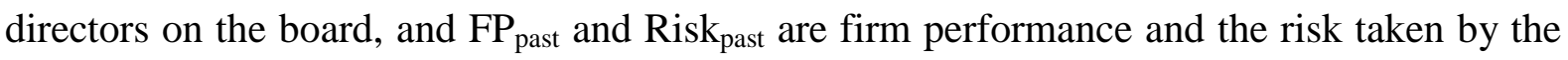
firm, respectively, in the past year. Since the residual $\varepsilon_{1}$ is free of the influences of lagged firm performance, past risk taken by the firm, the size of the supervisory board, and other

\footnotetext{
${ }^{3}$ The authors thank one of the anonymous reviewers for pointing out the recent studies on this topic.

${ }^{4}$ To adjust for distributional bias, we use the natural $\log$ of $(\mathrm{BCpay}+1)$ as the dependent variable in our tests, since the values of this variable are not normally distributed.
} 
explanatory factors, it may be interpreted as a measure of MISBMF, i.e., MISBMF $=\varepsilon_{1}$.

Control variables adopted for the current study include those measuring firm performance, risk taken by firms, agency effects, ownership structures of controlling shareholders, firm size, and industry effects. Financial performance of a firm usually has two major categories, the accounting return measured by return on assets (ROA) and return on equity (ROE) ${ }^{5}$, and the stock return. To measure risk taken by firms, we use the debt-equity ratio (D/E) determined by long-term debt over total equity. Other control variables include firm size (Conyon, 1997; Firth et al., 2006) measured by the natural log of total book value of assets (LnAssets), and industries categorized by the Chinese Securities Regulatory Commission (CSRC).

Corporate governance variables included the agency variable DUAL, a dummy variable indicating whether the chairman of the board of directors is also the CEO of the company, ownership structure variables such as GOV, a binary variable indicating whether the government or government representative is the largest shareholder, GOVSOE 6 , a dummy measuring whether the government, government representative, or a state-owned enterprise is the largest shareholder, and Herfindahl index (HHI) for the ten largest shareholders, excluding the largest one, as a control variable capturing ownership concentration. We also consider three variables to capture the potential effects of foreign shareholders among the ten largest ones. FOR is a dummy variable with a value of one for firms with a foreign shareholder as the largest one and zero otherwise, FOR10 is also a dummy variable indicating whether there is at least one foreign shareholder among the 10 largest ones, and FOR\% is a continuous variable measuring the total percentage of ownership held by foreign shareholders listed among the ten largest ones. In the Chinese markets, in addition, one of the unique features is the existence of non-tradable shares. Following the literature (e.g., Firth et al, 2006; Wang and Xu, 2004), we include, TRADE, the ratio of the number of tradable shares over that of total shares, as one of the control variables

\subsection{Methodology}

The OLS model used to test monitoring effects of supervisory board on board chair pay is

$$
\begin{aligned}
\text { LnBCPay }= & \gamma_{0}+\gamma_{1} \text { SBMF }+\gamma_{2} \text { SBS }+\gamma_{3} F P+\gamma_{4} \text { IBSize }+\gamma_{5} \text { Risk }+\gamma_{6} \text { LnAssets } \\
& +\gamma_{7} \text { Agency Var }+\gamma_{8} \text { Ownership StructureVar }+\gamma_{9} \text { Interactions } \\
& +\gamma_{10} \text { Industry Dummies }+\gamma_{11} \text { Year Dummies }+\varepsilon_{2}
\end{aligned}
$$

As discussed above, there are two aspects of the monitoring effects of supervisory board; the first is to help enhance the firm performance and then to increase the performance-related

\footnotetext{
${ }^{5}$ Note that we do not use Tobin's Q to measure firm performance, but use ROA and ROE to measure it. The reason is that most of Chinese publicly listed companies were converted from state-owned enterprises, and therefore a large portion of the shares are not tradable in the secondary market. As tradable and non-tradable shares have different market prices, using Tobin's Q to measure firm performance may be biased.

${ }^{6}$ Our measurement of SOE control adopts the method used in Firth et al. (2006), which examined ownership structure in a finer way. Our descriptive analysis shows the percentage of SOEs in our study is a little lower than that presented in prior studies (e.g. Firth et al. 2006, 2007). Two reasons may account for that difference. First, we are employing a more recent sample, i.e. year 2005 and 2006, while prior studies (e.g. Firth et al. 2006, 2007) used data until 2000 or 2003. Second, the privatization process has seen many family firms listed, which diluted the percentage of SOEs (e.g. Ding, Zhang, and Zhang, 2008).
} 
component of board chair pay, and the second is to help induce board chairs to better behave themselves and avoid overpaying themselves. Therefore, the main research questions in this study are tested by the signs for $\gamma_{1}$ and $\gamma_{2}$. If $\gamma_{i}(i=1,2)$ is significantly positive, the first aspect of the monitoring effects dominates the second, while the second dominates the firm if $\gamma_{i}$ is significantly negative.

However, firm performance and risk may affect the board chair pay in two ways, one of which is an indirect relationship between characteristics of supervisory board and board chair pay. As stated above, the meeting frequency of supervisory board can be jointly determined by the size of supervisory board, the lagged firm performance, the past risk taken by the firm, and other control variables. Thus, it is important to separate the monitoring-driven supervisory board meeting frequency (MISBMF) from those effects. Control variables which should be taken into consideration in Equation (1) include the firm size (LnAssets), ownership structure variables for the state-owned and foreign shareholders, and a dummy variable indicating whether there is a turnover of the chairman of the supervisory board (SBCTurnover). Including SBCTurnover is consistent with the corporate governance literature (e.g., Huson, 2001; Goyal and Park, 2002; Fee and Hadlock, 2004), and it is reasonable to believe that a firm with a turnover of the chairman of the supervisory board may meet more frequently to make the transition smooth. Therefore, a 2SLS model is adopted to illustrate this subtle effect with Equation (1) as the first stage and Model (2) as the second, at which we use MISBMF to replace SBMF. Doing so also further helps mitigate the potential endogeneity caused by the interaction between firm performance and characteristics of supervisory board, and strengthens the validity of the analysis.

To better illustrate the monitoring effects of major features of supervisory board in Chinese publicly listed firms, we further investigate the board chair pay-supervisory board sensitivity by characterizing the marginal effects of change in meeting frequency, as well as those of change in size of supervisory board, on the change in board chair pay. In the board chair pay-supervisory board sensitivity analysis, we use the change in the compensation of board chair ( $\triangle \mathrm{BCPay}$ ) from 2005 to 2006 as the dependent variable, and the change in the supervisory board meeting frequency $(\triangle \mathrm{SBMF})$ between the two years and that in the size of supervisory board $(\triangle \mathrm{SBS})$ as the independent variables. Major control variables include the change in firm size ( $\triangle$ Assets) from 2005 to 2006 , the change in risk taken by the firm ( $\Delta$ Risk) measured by the $\mathrm{D} / \mathrm{E}$ ratio $(\Delta \mathrm{D} / \mathrm{E})$, the change in firm performance $(\Delta \mathrm{FP})$, and twelve industry dummies. Therefore, the basic model for the board chair pay-supervisory board sensitivity analysis is

$$
\triangle B C P a y=\beta_{0}+\beta_{1} \Delta S B M F+\beta_{2} \Delta S B S+\beta_{3} \Delta F P+\beta_{4} \Delta \text { Risk }+\beta_{5} \Delta \text { Assets }+\beta_{6} \text { Industry Dummies }+\varepsilon_{3}
$$

The pay-supervisory board sensitivity analysis is pushed forward by controlling ownership structure of dominant shareholders following existing literature (e.g., Chen et al., 2006; Firth et al., 2006) to discover the marginal effects of supervisory board in firms with state-owned largest shareholders and those with foreign shareholders among the ten largest ones. 


\section{Results and Discussion}

\subsection{Descriptive Statistics}

We present the descriptive statistics for the sample firms in Table 1. In Year 2005 and Year 2006, the average board chair pay per year was RMB181,630, and the average of its natural logarithm was 7.809. The average supervisory board meeting frequency was 3.577 times in a year, and the average size of the supervisory board was 4.146 members. $35.5 \%$ of the companies experienced a turnover of the supervisory board chair. The average number of independent directors on the board of directors was 3.31. Firm performance measured by ROE was $4.6 \%$, and the average risk taken by firms was an average D/E ratio of 0.231 . Board chairs in $12 \%$ of the firms were also the CEOs, $27.3 \%$ of them had their largest shareholders government-controlled, and $1.9 \%$ of them had foreign largest shareholders. The average level of ownership concentration measured by HHI was 0.0205 , and $45.2 \%$ of shares were tradable. The average firm size measured by the total book value of assets was RMB3,870 Million.

Table 1 Descriptive Statistics

\begin{tabular}{|l|c|c|c|}
\hline & Mean & S.D. & N \\
\hline BCPay & 181,630 & 351,411 & 2712 \\
\hline LnBCpay & 7.809 & 5.824 & 2712 \\
\hline SBMF & 3.577 & 1.676 & 2754 \\
\hline SBS & 4.146 & 1.44 & 2762 \\
\hline SBCTurnover & 0.355 & 0.479 & 2648 \\
\hline IBSize & 3.310 & 0.762 & 2762 \\
\hline ROE & 0.046 & 2.328 & 2742 \\
\hline D/E & 0.231 & 1.037 & 2742 \\
\hline DUAL & 0.12 & 0.326 & 2716 \\
\hline GOV & 0.273 & 0.446 & 2914 \\
\hline GOVSOE & 0.509 & 0.5 & 2914 \\
\hline FOR & 0.019 & 0.135 & 2914 \\
\hline FOR10 & 0.094 & 0.291 & 2914 \\
\hline FOR\% & 8.351 & 11.058 & 273 \\
\hline HHI & 0.0205 & 0.0269 & 2762 \\
\hline TRADE & 0.452 & 0.136 & 2762 \\
\hline Assets (million RMB) & 3,870 & 17,300 & 2742 \\
\hline LnAssets & 21.247 & 1.113 & 2742 \\
\hline
\end{tabular}

Description for the above table: The variable BCPay represents the board chair pay. The variable LnBCPay is the natural log of BCPay. SBMF measures the meeting frequency of supervisory board, and SBS is its size. SBCTurnover is a dummy variable which measures whether there is a turnover of the chairman of supervisory board in a year. IBSize indicates the number of independent directors on the board. ROE is the return on equity which is the ratio between net income and total equity. D/E is a firm's debt-equity ratio calculated by long-term debt over total equity. DUAL is a dummy variable which indicates whether the chairman of the board of directors is also the CEO of the company. GOV 
is a binary variable indicating whether the government or government representative is the largest shareholder, and GOVSOE is another binary variable measuring whether the government, government representative, or a state-owned enterprise is the largest shareholder. FOR is a dummy variable with a value of one for firms with a foreign shareholder as the largest one and zero otherwise, FOR10 is also a dummy variable indicating whether there is at least one foreign shareholder among the 10 largest ones, and FOR\% is a continuous variable measuring the total percentage of ownership held by foreign shareholders listed among the 10 largest ones. The Herfindahl index (HHI) captures the major features of ownership concentration for the 10 largest shareholders, excluding the largest one. TRADE is the ratio between the number of tradable shares and that of total shares. The variable Assets indicates the firm size measured by the total book value of assets, and LnAssets is the natural $\log$ of it.

\subsection{Monitoring Effects of Supervisory Board}

Table 2 presents the results from estimating the monitoring effects of supervisory board on the board chair pay based on the OLS and the 2SLS models, respectively. Empirical results obtained from the OLS regressions, including or excluding the interaction terms, are presented in Panel A. These interaction terms include those between firm performance and ownership structure variables, and those between supervisory board variables and ownership structure variables. Results from the 2SLS models are presented in Panel B.

It is clear that the empirical findings from these two models are consistent, and to some degree, they serve as a robustness test for each other. Results from the first stage of the 2SLS model, with the supervisory board meeting frequency (SBMF) as the dependent variable, are also presented in Panel B of Table 2. Findings are summarized as follows.

Table 2 Monitoring Effects of Supervisory Board on Board Chair Pay

Panel A. OLS Regressions and Tobit Analysis

\begin{tabular}{|c|c|c|c|c|c|c|c|c|}
\hline & \multicolumn{4}{|c|}{ OLS Regressions } & \multicolumn{4}{c|}{ Tobit Analysis } \\
\cline { 2 - 9 } & Coefficient & S.D. & Coefficient & S.D. & Coefficient & S.D. & Coefficient & S.D. \\
\hline SBMF & -0.023 & $(0.070)$ & -0.084 & $(0.081)$ & -0.033 & $(0.108)$ & -0.123 & $(0.125)$ \\
\hline SBS & -0.125 & $(0.085)$ & $-0.251^{* *}$ & $(0.104)$ & -0.189 & $(0.133)$ & $-0.380^{* * *}$ & $(0.162)$ \\
\hline IBSize & $-0.280^{*}$ & $(0.160)$ & $-0.273^{* *}$ & $(0.160)$ & $-0.453^{*}$ & $(0.278)$ & $-0.446^{*}$ & $(0.248)$ \\
\hline ROE & -0.086 & $(0.064)$ & -0.134 & $(0.085)$ & -0.144 & $(0.099)$ & $-0.238^{*}$ & $(0.143)$ \\
\hline D/E & 0.143 & $(0.114)$ & 0.112 & $(0.120)$ & 0.223 & $(0.174)$ & 0.174 & $(0.183)$ \\
\hline DUAL & $4.378^{* * *}$ & $(0.342)$ & $4.316^{* * *}$ & $(0.342)$ & $6.183^{* * *}$ & $(0.511)$ & $6.084^{* * * *}$ & $(0.510)$ \\
\hline GOV & -0.125 & $(0.255)$ & $-2.717^{* * *}$ & $(0.904)$ & -0.153 & $(0.395)$ & $-4.083^{* * * *}$ & $(1.402)$ \\
\hline FOR & $-1.832^{* *}$ & $(0.830)$ & 2.400 & $(3.588)$ & $-3.152^{* *}$ & $(1.327)$ & 5.261 & $(6.114)$ \\
\hline ROExGOV & & & 0.109 & $(0.128)$ & & & 0.187 & $(0.201)$ \\
\hline ROExFOR & & & 4.303 & $(5.073)$ & & & 9.174 & $(10.434)$ \\
\hline SBMFxGOV & & & $0.287^{*}$ & $(0.151)$ & & & $0.426^{*}$ & $(0.233)$ \\
\hline SBMFxFOR & & & $-0.836^{* *}$ & $(0.490)$ & & & $-1.497^{* *}$ & $(0.808)$ \\
\hline SBSxGOV & & & $0.370^{* *}$ & $(0.170)$ & & & $0.570^{* * *}$ & $(0.264)$ \\
\hline SBSxFOR & & & -0.323 & $(0.724)$ & & & -0.871 & $(1.244)$ \\
\hline
\end{tabular}




\section{Macrothink}

Asian Journal of Finance \& Accounting ISSN 1946-052X 2009, Vol. 1, No. 1: E1

\begin{tabular}{|c|c|c|c|c|c|c|c|c|}
\hline HHI & $0.001^{* * *}$ & $(0.004)$ & $0.001^{* * *}$ & $(0.004)$ & $0.002^{* * *}$ & $(0.001)$ & $0.002^{* * * *}$ & $(0.001)$ \\
\hline TRADE & $4.936^{* * *}$ & $(0.910)$ & $4.940^{* * *}$ & $(0.909)$ & $7.627^{* * * *}$ & $(1.415)$ & $7.599^{* * * *}$ & $(1.412)$ \\
\hline LnAssets & $-0.256^{* *}$ & $(0.112)$ & $-0.262^{* *}$ & $(0.112)$ & $-0.513^{* * * * *}$ & $(0.176)$ & $-0.517^{* * * *}$ & $(0.176)$ \\
\hline Industry Dummies & \multicolumn{2}{|c|}{ Included and mixed } & \multicolumn{2}{|c|}{ Included and mixed } & \multicolumn{2}{|c|}{ Included and mixed } & \multicolumn{2}{|c|}{ Included and mixed } \\
\hline Year Dummy & $-0.470^{*}$ & $(0.241))$ & $-0.471^{*}$ & $(0.241)$ & $-0.747^{* *}$ & $(0.373)$ & $-0.745^{* *}$ & $(0.372)$ \\
\hline CONSTANT & $11.434^{* * *}$ & $(2.351)$ & $12.251^{\text {*** }}$ & $(2.369)$ & $14.285^{\text {**** }}$ & $(3.685)$ & $15.443^{\text {*** }}$ & $(3.707)$ \\
\hline $\mathrm{N}$ & \multicolumn{2}{|c|}{2580} & \multicolumn{2}{|c|}{2580} & \multicolumn{2}{|c|}{2580} & \multicolumn{2}{|c|}{2580} \\
\hline Adj./Pseudo R ${ }^{2}$ & \multicolumn{2}{|c|}{0.080} & \multicolumn{2}{|c|}{0.094} & \multicolumn{2}{|c|}{0.017} & \multicolumn{2}{|c|}{0.018} \\
\hline$F$-Value & \multicolumn{2}{|c|}{$10.36^{* * *}$} & \multicolumn{2}{|c|}{$8.79^{\text {**** }}$} & & & & \\
\hline LR Chi-square & & & & & \multicolumn{2}{|c|}{$230.65^{* * * *}$} & \multicolumn{2}{|c|}{$245.74^{* * * *}$} \\
\hline
\end{tabular}

Panel B. 2-Stage Models

\begin{tabular}{|c|c|c|c|c|c|c|}
\hline & \multicolumn{2}{|c|}{ Stage 1} & \multicolumn{2}{|c|}{ Stage 2: OLS } & \multicolumn{2}{|c|}{ Stage 2: Tobit } \\
\hline & Coefficient & S.D. & Coefficient & S.D. & Coefficient & S.D. \\
\hline Dep. Var. & \multicolumn{2}{|c|}{ SBMF } & \multicolumn{2}{|c|}{ LnBCPay } & \multicolumn{2}{|c|}{ LnBCPay } \\
\hline MISBMF & & & -0.059 & $(0.089)$ & -0.084 & $(0.139)$ \\
\hline SBS & $0.078^{* * *}$ & $(0.024)$ & $-0.257^{* *}$ & $(0.107)$ & $-0.390^{* *}$ & $(0.168)$ \\
\hline IBSize & -0.023 & $(0.046)$ & $-0.318^{*}$ & $(0.166)$ & $-0.523^{* *}$ & $(0.260)$ \\
\hline SBCTurnover & $1.067^{* * *}$ & $(0.065)$ & & & & \\
\hline ROEpast & 0.008 & $(0.010)$ & & & & \\
\hline ROE & & & $-0.146^{*}$ & $(0.086)$ & $-0.261^{*}$ & $(0.149)$ \\
\hline D/Epast & -0.055 & $(0.023)$ & & & & \\
\hline $\mathrm{D} / \mathrm{E}$ & & & 0.089 & $(0.121)$ & 0.141 & $(0.187)$ \\
\hline DUAL & & & $4.371^{* * * *}$ & $(0.355)$ & $6.210^{* * *}$ & $(0.534)$ \\
\hline GOV & $-0.199^{* * *}$ & $(0.071)$ & $-1.931^{* *}$ & $(0.787)$ & $-2.962^{* *}$ & $(1.235)$ \\
\hline FOR & 0.056 & $(0.233)$ & -1.089 & $(3.026)$ & -0.882 & $(5.175)$ \\
\hline ROExGOV & & & 0.120 & $(0.129)$ & 0.208 & $(0.206)$ \\
\hline ROExFOR & & & 4.534 & $(5.117)$ & 9.809 & $(10.599)$ \\
\hline MISBMFxGOV & & & $0.301^{*}$ & $(0.164)$ & $0.455^{*}$ & $(0.257)$ \\
\hline MISBMFxFOR & & & -0.565 & $(0.572)$ & -1.065 & $(0.949)$ \\
\hline SBSxGOV & & & $0.416^{* *}$ & $(0.174)$ & $0.645^{* *}$ & $(0.274)$ \\
\hline SBSxFOR & & & -0.292 & $(0.748)$ & -0.820 & $(1.304)$ \\
\hline HHI & & & $0.001^{* * *}$ & $(0.000)$ & $0.002^{* * *}$ & $(0.001)$ \\
\hline TRADE & & & $4.883^{* * *}$ & $(0.927)$ & $7.611^{* * *}$ & $(1.455)$ \\
\hline LnAssets & $0.105^{* * *}$ & $(0.031)$ & $-0.243^{* *}$ & $(0.115)$ & $-0.497^{* * * *}$ & $(0.182)$ \\
\hline Industry Dummies & \multicolumn{2}{|c|}{ Included and mixed } & \multicolumn{2}{|c|}{ Included and mixed } & \multicolumn{2}{|c|}{ Included and mixed } \\
\hline Year Dummy & & & $-0.441^{*}$ & $(0.250)$ & $-0.710^{*}$ & $(0.391)$ \\
\hline CONSTANT & $1.064^{*}$ & $(0.641)$ & $11.732^{* * *}$ & $(2.433)$ & $14.733^{* * *}$ & $(3.845)$ \\
\hline $\mathrm{N}$ & \multicolumn{2}{|c|}{2540} & \multicolumn{2}{|c|}{2459} & \multicolumn{2}{|c|}{2459} \\
\hline Adj./Pseudo $\mathrm{R}^{2}$ & \multicolumn{2}{|c|}{0.114} & \multicolumn{2}{|c|}{0.082} & \multicolumn{2}{|c|}{0.018} \\
\hline$F$-Value & \multicolumn{2}{|c|}{$17.32^{* * *}$} & \multicolumn{2}{|c|}{$8.33^{* * *}$} & & \\
\hline LR Chi-square & & & & & \multicolumn{2}{|c|}{$232.50^{* * *}$} \\
\hline
\end{tabular}


$\mathrm{p}<0.01,{ }^{* *} \mathrm{p}<0.05,{ }^{*} \mathrm{p}<0.10 . \mathrm{N}$ is the number of observations.

First, according to the results from the first stage of the 2SLS model, a larger supervisory board size and an occurrence of a turnover of supervisory board chair significantly increase the number of meetings held by supervisory board members at the $1 \%$ level $^{7}$. These results are as expected. The former effect is potentially due to the lower efficiency of reaching agreement among the members on a larger supervisory board, and the latter effect could show that, if there is a turnover of the chairman of supervisory board in a year, the supervisory board meets more to ensure a smooth transition. In addition, companies with the largest shareholder controlled by government are likely to hold less supervisory board meetings due to the special natures of state-owned or state-controlled enterprises. Consistent with the results presented in the literature (Vafeas, 1999; Firth et al., 2006, 2007), furthermore, a firm with a larger size (LnAssets) tends to have more supervisory board meetings.

We do not find significant effects of risk taken by the firm in the past year or those of lagged firm performance on the meeting frequency of supervisory board. These results mainly indicate that the supervisory boards in Chinese publicly listed companies are not responsible for their daily operation issues, but only for monitoring the behaviors of board of directors and those of top management team (Xi, 2006; Firth et al., 2006). After taking away the influences of the size of supervisory board, past risk taken by the company, and lagged firm performance, on the variable SBMF, we generate a new variable MISBMF to measure the monitoring-induced supervisory board meeting frequency using the residuals from the first stage of the 2SLS model, and use it at the second stage.

Second, while the effects of supervisory board meeting frequency on the board chair pay are insignificant, those of the size of supervisory board are significant at the $1 \%$ level. A larger supervisory board tends to reduce the compensation received by board chairs. A possible interpretation is that companies with larger supervisory boards tend to monitor the behaviors of board chairs more efficiently and to lower their compensations. We also find that the number of independent directors (IBSize) has a negative relationship with the dependent variable LnBCPay at the $10 \%$ significance level. More independent directors on the board of directors help lower the compensation received by board chairs.

What should be further highlighted is that in government controlled companies, both the supervisory board meeting frequency and the number of members on the supervisory board increase the board chair pay significantly (at the 5\% level). These results indicate that generally, the monitoring effects of supervisory board for enhancing firm performance may dominate those for avoiding overpays. In these companies, the executives, who are usually representatives of controlling shareholders, may be more likely to receive the fixed component of their compensations from their host organizations and the performance-related component from the publicly listed companies. In these state-controlled companies, therefore, a higher meeting frequency held by supervisory board is more likely to enhance the firm performance,

\footnotetext{
${ }^{7}$ SBCTurnover is the instrumental variable.
} 
which can consequently increase the performance-related component of executive compensation. Generally, however, board chairs in state-owned or state-controlled companies are more likely to have lower compensation in the publicly listed companies than other board chairs. This may be explained by the fact that board chairs of these companies are also likely to be the government officials or their representatives of governmental and state-controlled organizations, and therefore, they may get paid in their host organizations.

In addition, companies whose CEOs are also board chairs tend to pay more to their board chairs, and this may be explained in two ways. First, this situation of owner-management reduces the principal-agent agency conflict caused by ownership separation, and therefore helps enhance the firm performance, which may increase the performance-based compensation of board chairs indirectly. Second, since the CEOs are also board chairs, they may have more significant influences on the board decisions about their compensations; in other words, this phenomenon that a CEO is also the board chair may reduce the monitoring effects of supervisory board.

Furthermore, control variables, such as ownership concentration (HHI), the percentage of tradable shares (Trade), and firm size (LnAssets), also influence the board chair pay significantly at the $1 \%$ level; the first two have positive effects, while the third one has negative effects. Some industry dummies are also shown to be significant. These results are consistent with those presented by prior studies in the literature (e.g., Murphy, 1999; Firth et al, 2006).

\subsection{Board Chair Pay-Supervisory Board Sensitivity Results}

To further investigate the board chair pay-supervisory board relationship, we analyze the pay-supervisory board sensitivity in the full sample, and in the subsamples with special features of controlling ownership such as government control and foreign largest shareholders, respectively. Empirical results are presented in Table 3.

In the full sample, the change in the size of supervisory board ( $\triangle \mathrm{SBS})$ is positively related to the change in the board chair pay ( $\triangle \mathrm{BCPay}$ ) at the $5 \%$ significance level. This result indicates that before and after the new Corporate Law became effective on January 1, 2006, when the change in the number of supervisory board members increased by 1 from 2005 to 2006, the change in the board chair pay increased by RMB14,970.89. This partially shows that the enforcement of new Corporate Law significantly improves the monitoring effects of supervisory board on firm performance from 2005 to 2006, which leads to a higher board chair pay.

Following extant research (e.g., Chen, et al., 2006; Firth, et al, 2006) in the literature, we also investigate the board chair pay-supervisory board sensitivity in sub-samples featured by ownership structures. As shown by the empirical results presented in Table 3, we find a positive relationship between the change in SBS $(\triangle \mathrm{SBS})$ and the change in the compensation of board chairs $(\triangle \mathrm{BCPay})$ at the $1 \%$ significance level in firms with government-controlled largest shareholders. In these firms, when the change in the number of supervisory board members increased by 1 , the change in the board chair pay increased by RMB41,911.81. Hence, in government controlled firms, board chair pay was sensitive to the supervisory board size, but 
not to the supervisory board meetings frequency, firm performance, financial leverage risk or asset size. In other words, it may be more effective to improve firm performance and board chair pay by increasing supervisory board size in government controlled firms than in other firms. In firms with foreign largest shareholders, however, we do not observe a positive relationship between $\triangle \mathrm{SBS}$ and $\triangle \mathrm{BCPay}$.

\subsection{Robustness Tests}

To further ensure the validity of the empirical results presented in this study, robustness tests are done using both different estimation methods and different variables to capture similar effects. As discussed above, the dependent variable LnBCPay, which measures the board chair pay, is left-censored since some of them do not get paid in these publicly listed companies. Therefore, Tobit models are used to deal with potential biases caused by this situation. Two sets of the above analysis are replicated, and they are the Tobit analysis based on Model (2) and the 2-stage model with Tobit as the second stage. Results are presented in Panels A and B of Table 2 , and no qualitative change has been found.

To further address a potential overlap of the monitoring functions of supervisory board and independent directors, we rerun the tests by excluding the variable IBSize from the analysis, but do not find any qualitative change. We also test the results for robustness by using alternative proxies for financial performance, risk taken by firms, and ownership structure variables. We have found no qualitative change in the results.

To check for multicollinearity, we examine the variance inflation factors (VIF) for the variables. The VIFs are all under 10, indicating that no multicollinearity problem is serious. The robustness of the pay-supervisory board sensitivity results is also tested by using alternative proxies for ownership structure, and no qualitative change is found. In a word, therefore, we conclude that Hypothesis 1 is rejected, but Hypothesis 2 is not.

Table 3 Results from Pay-Supervisory Board Sensitivity

\begin{tabular}{|c|c|c|c|}
\hline & Raw Sample & GOV=1 & FOR=1 \\
\hline Dep. Var. & $\Delta$ BCPay & $\Delta$ BCPay & $\Delta$ BCPay \\
\hline$\Delta$ SBMF & -1909.247 & -1251.789 & 17220.16 \\
\hline & $(2183.10)$ & $(4413.65)$ & $(19449.69)$ \\
\hline$\Delta$ SBS & $14970.89^{* * *}$ & $41911.81^{* * * *}$ & 40396.68 \\
\hline & $(7278.37)$ & $(14345.69)$ & $(78855.56)$ \\
\hline$\Delta$ ROE & 684.781 & 1761.114 & -113567.1 \\
\hline & $(1661.69)$ & $(2857.51)$ & $(83809.20)$ \\
\hline$\Delta$ D/E & 153.73 & -11558.68 & -382842 \\
\hline & $(3002.88)$ & $(16407.11)$ & $(276364.90)$ \\
\hline Assets & 0.000 & 0.000 & 0.000 \\
\hline & $(0.000)$ & $(0.000)$ & $(0.000)$ \\
\hline Industry Dummies & Included and mixed & Included and mixed & Included and mixed \\
\hline & & & -22906.36 \\
\hline CONSTANT & -7513.121 & -35933.94 & \\
\hline
\end{tabular}




\begin{tabular}{|c|c|c|c|}
\hline & (17402.66) & $(39434.24)$ & $(103279.40)$ \\
\hline $\mathrm{N}$ & 1290 & 283 & 27 \\
\hline Adj. $R^{2}$ & 0.002 & 0.024 & -0.074 \\
\hline$F$-Value & 1.17 & 1.43 & 0.78 \\
\hline
\end{tabular}

\section{Conclusions and Future Research}

China is one of the most fast-growing emerging markets in the global economy, and financial integration which has become increasingly popular is of importance for international investors. During the transition from planned to market-based economy in China since late 1970's, the Corporate Law was amended three times to further improve the efficiency of corporate governance mechanisms; the most recent one occurred in 2005 and became effective on January 1, 2006. The Chinese governance mechanism combines the Anglo-American and the German systems, and therefore requires having two monitoring organs, independent directors and supervisory boards. While supervisory boards in Chinese publicly listed firms have not been considered to function well according to previous studies, the newly amended Corporate Law 2006 significantly strengthens the monitoring of supervisory boards to help improve the efficiency of corporate governance mechanisms.

In the corporate governance literature, the roles of supervisory board are rarely addressed, and therefore, we are among the first to examine its effects on executive compensation. More importantly, we examine the board chair pay-supervisory board relationship by looking deeply into supervisory boards' characteristics and activities, such as their meeting frequencies and sizes. Multiple contributions are made to both the academic literature and the practice. In more detail, findings in the current study do not only add to the literature on corporate governance under agency theory, but also provide crucial policy implications for both the Chinese authorities and other emerging markets in the world.

According to prior research in the corporate governance literature (Shleifer and Vishny, 1997), two layers of monitoring effects of supervisory board on executive compensation are observed. The first layer says that supervisory board helps induce the chairman of board of directors to better behave themselves and avoid overpaying themselves, and the second is that supervisory board may help enhance firm performance, a basis of the incentive component of executive compensation. These two layers of monitoring effects show the effectiveness of supervisory board in the dual-board corporate governance mechanism in China.

The major finding of this study is that the size of supervisory board is shown to be negatively related to the board chair pay, presumably because the monitoring effects of the size of supervisory board on board chair's behaviors dominate those on firm performance. A larger supervisory board tends to meet more frequently, and the joint effects between meeting frequency and size of supervisory board are taken into account. The same monitoring effects as 
above are found. We also find a high level of board chair pay-supervisory board sensitivity in the Chinese publicly listed companies in Year 2005 and Year 2006. These results are counter-intuitive since they are opposite to the findings presented in previous studies. To some extent, these illustrate that the effectiveness of corporate governance mechanism in Chinese publicly listed companies has been dramatically strengthened. This is partially shown by the improvement in the functionality of one of the important monitoring organs in the dual-board corporate governance mechanism in Chinese publicly listed companies. Prior research finds supervisory board's functionality was very weak, and findings of this study indicate that it has been strengthened after the newly-amended Corporate Law was effective at the beginning of Year 2006.

Future research can be done along this line by further investigating the effects of supervisory board on the unique corporate governance mechanism in Chinese markets. For instance, effects of supervisory board characteristics and activities on firm performance, those on risk taken by firms, and those on financial frauds are three issues which are of importance and of interest for both academic researchers and policy makers

\section{Acknowledgement}

We appreciate the helpful comments from two anonymous referees and participants at the 2008 Research Symposium on Corporate Governance in China and India, Virginia Beach, VA, co-sponsored by Corporate Governance, Old Dominion University, and Wiley-Blackwell.

\section{References}

Aggarwal, R.K., \& Samwick, A.A. (1999), Executive compensation, strategic competition, and relative performance evaluation: Theory and evidence. Journal of Finance, 54, 1999-2043.

Aggarwal, R.K., \& Samwick, A.A. (2003), Performance incentives within firms: The effect of managerial responsibility. Journal of Finance, 58, 1613-1649.

Anderson, R., \& Bizjak, J. (2003), An empirical examination of the role of the CEO and the compensation committee in structuring executive pay. Journal of Banking and Finance, 27, 1323-1348.

Anderson, R., \& Reeb, D. (2003), Founding-family ownership and firm performance: Evidence from the S\&P 500. Journal of Finance, 58, 1301-1328.

Anderson, R., Mansi, S., \& Reeb, D. (2003), Founding family ownership and the agency cost of debt. Journal of Financial Economics, 68, 263-285.

Ang, J.S., Cole, R.A. \& Lin, J.W. (2000), Agency costs and ownership structure. Journal of Finance, 55, 81-106.

Angel, J.J., \& McCabe, D.M. (2008), The ethics of managerial compensation: The case of executive stock options. Journal of Business Ethics, 78, 225-235.

Ashley, A.S., \& Yang, S.S.M. (2004), Executive compensation and earnings persistence. Journal of Business Ethics, 50, 369-382. 
Bai, C., Liu, Q., Lu, J., Song, F.M., \& Zhang, J. (2004), Corporate governance and market valuation in China. Journal of Comparative Economics, 32, 599-616.

Balsam, S., \& Miharjo, S. (2007), The effects of equity compensation on voluntary executive turnover. Journal of Accounting and Economics, 43, 95-119.

Boyd, B. (1994), Board control and CEO compensation. Strategic Management Journal, 15, 335-344.

CFA Institute, (2007), China Corporate Governance Survey. ISBN: 978-1-932495-65-2 (PDF).

Chen, G.M., Firth, M., Gao, D.N., \& Rui, O.M. (2006), Ownership structure, corporate governance, and fraud: Evidence from China. Journal of Corporate Finance, 12, 424-448.

Chhaochharia, V., \& Grinstein, Y. (2008), CEO compensation and board structure. Working paper, [online] available at SSRN: http://ssrn.com/abstract=901642

Conyon, M.J. (1997), Corporate governance and executive compensation. International Journal of Industrial Organization, 15, 493-509.

Cordeiro, J.J., Veliyath, R., \& Romal, J.B. (2007), Moderators of the relationship between director stock-based compensation and firm performance. Corporate Governance: An International Review, 15, 1384-1393.

Core, J., Holthausen, R., \& Larcker, D. (1999), Corporate governance, chief executive officer compensation and firm performance. Journal of Financial Economics, 51, 371-406.

Dahya, J., Karbhari, Y., Xiao, J., \& Yang, M. (2003), The usefulness of the supervisory in China. Corporate Governance: An International Review, 11, 308-321.

Ding, Y., Zhang, H., \& Zhang, J. (2008), The financial and operating performance of Chinese family-owned listed firms. Management International Review, 48, 297-318.

Devers, C.E., Cannella, Jr., A.A., Reilly, G.P., \& Yoder, M.E. (2007), Executive compensation: A multidisciplinary review of recent developments. Journal of Management, 33, 1016-1072.

Dutta, S. (2003), Capital budgeting and managerial compensation: Incentive and retention effects. Accounting Review, 78, 71-93.

Elston, J., \& Goldberg, L. (2003), Executive compensation and agency costs in Germany. Journal of Banking \& Finance, 27, 1391-1410.

Fee, C.E., \& Hadlock, C.J. (2004), Management turnover across the corporate hierarchy. Journal of Accounting and Economics, 37, 3-38.

Firth, M., Fung, P., \& Rui, O. (2006), Corporate performance and CEO compensation in China. Journal of Corporate Finance, 12, 693-714.

Firth, M., Fung, P., \& Rui, O. (2007), Ownership, two-tier board structure, and the informativeness of earnings - evidence from China. Journal of Accounting and Public Policy, 
26, 463-496.

Fosberg, R.H. (2001), CEO replacement and compensation around dividend omissions. Corporate Governance: An International Review, 9, 25-36.

Goyal, V., \& Park, C. (2002), Board leadership structure and CEO turnover. Journal of Corporate finance, 8, 49-66.

Guedj, I., \& Barnea, A. (2009), Director networks. Working paper, [online] available at SSRN: http://ssrn.com/abstract $=966555$.

Hall, B.J., \& Liebman, J.B. (1998), Are CEOs really paid like bureaucrats? Quarterly Journal of Economics, 113, 653-691.

Hartzell, J., \& Starks, L. (2003), Institutional investors and executive compensation. Journal of Finance, 58, 2351-2374.

Haw, I., Qi, D., Wu, D., Wu, W. (2005), Market consequences of earnings management in response to security regulations in China. Contemporary Accounting Research, 22, 95-140.

Huson, M. (2001), Internal monitoring and CEO turnover: A long-term perspective. Journal of Finance, 56, 2265-2297.

Jensen, M.C. (1993), The modern industrial revolution, exit, and the failure of internal control systems. Journal of Finance, 48, 831-880.

Jensen, M., \& Murphy, K.J. (1990), Performance and top management incentives. Journal of Political Economy, 98, 225-264.

Jensen, M.C., \& Meckling, W.H. (1976), Theory of the firm: Managerial behavior, agency costs and ownership structure. Journal of Financial Economics, 3, 305-360.

Jia, C. (2009), The effect of ownership on the prudential behavior of banks - the case of China. Journal of Banking and Finance, 33, 77-87.

Jia, C., Ding, S., Li, Y., \& Wu, Z. (2009), Fraud, enforcement action, and the role of corporate governance: Evidence from China. Journal of Business ethics, forthcoming.

Kato, T., \& Long, C. (2006), Executive compensation, firm performance, and corporate governance in China: Evidence from firms listed in the Shanghai and Shenzhen stock exchanges. Economic Development and Cultural Change, 54, 945-983.

Ke, B., Petroni, K., \& Safieddine, A. (1999), Ownership concentration and sensitivity of executive pay to accounting performance measures: Evidence from publicly and privately-held insurance companies. Journal of Accounting and Economics, 28, 185-209.

Kraft, K., \& Niederprum, A. (1999), Determinants of management compensation with risk-averse agents and dispersed ownership of the firm. Journal of Economic Behavior and Organization, 40, 17-27.

La Porta, R., Lopez-de-Silanes, F., \& Shleifer, A. (1999), Corporate ownership around the 
world. Journal of Finance, 54, 471-517.

La Porta, R., Lopez-de-Silanes, F., Shleifer, A, \& Vishny, R. (2000), Investor protection and corporate governance. Journal of Financial Economics, 58, 3-27.

Levitt, A. (2005), Corporate culture and the problem of executive compensation. Journal of Applied Corporate Finance, 17, 41-43.

Lin, Y. (2005) Corporate governance, leadership structure and CEO compensation: Evidence from Taiwan. Corporate Governance: An International Review 13, 824-835.

Liu, D., \& Otsuka, K. (2004), A comparison of management incentives, abilities, and efficiency between SOEs and TVEs: The case of the iron and steel industry in China. Economic Development and Cultural Change, 52, 759-780.

Liu, G.S., \& Sun, P. (2005), The class of shareholdings and its impacts on corporate performance: A case of state shareholding composition in Chinese public corporations. Corporate Governance: An International Review, 13, 46-59.

Mahoney, L.S., \& Thorn, L. (2006), An examination of the structure of executive compensation and corporate social responsibility: A Canadian investigation. Journal of Business Ethics, 69, 149-162.

Matsumura, E.M., \& Shin, J.Y. (2005), Corporate governance reform and CEO compensation: Intended and unintended consequences. Journal of Business Ethics, 62, 101-113.

Mengistae, T., \& Xu, L. (2004), Agency theory and executive compensation: The case of Chinese state-owned enterprises. Journal of Labor Economics, 22, 615-637.

Murphy, K. (1999), Executive Compensation. Handbook of Labor Economics Vol. 3 (Elsevier).

Nagar, V. (2002), Delegation and innovative compensation. Accounting Review, 77, 379-395.

Nichols, D., \& Subramaniam, C. (2001), Executive compensation: Excessive or equitable? Journal of Business Ethics, 29, 339-351.

Ortiz-Molina, H. (2007), Executive compensation and capital structure: The effects of convertible debt and straight debt on CEO pay. Journal of Accounting and Economics, 43, 69-93.

Perel, M. (2003), An ethical perspective on CEO compensation. Journal of Business Ethics, 48, 381-391.

Persons, O. (2006), The effects of fraud and lawsuit revelation on U.S. executive turnover and compensation. Journal of Business Ethics, 64, 405-419.

Pistor, K., \& Xu, C. (2005), Governing emerging stock markets: Legal vs administrative governance. Corporate Governance: An International Review, 13, 5-10.

Ramaswamy, K., Veliyath, R., \& Gomes, L. (2000), A study of the determinants of CEO 
compensation in India. Management International Review 40, 167-191.

Ryan Jr., H., \& Wiggins III, R. (2004), Who is in whose pocket? Director compensation, board independence, and barriers to effective monitoring. Journal of Financial Economics, 73, 497-524.

Shleifer, A., \& Vishny, R. (1997), A survey of corporate governance. Journal of Finance, 52, 737-783.

Sun, Q., \& Tong, W.H.S. (2003), China share issue privatization: The extent of its success. Journal of Financial Economics, 70, 183-222.

Vafeas, N. (1999), Board meeting frequency and firm performance. Journal of Financial Economics, 53, 113-142.

Wang, M. (2005), Independent directors? Supervisors? Who should monitor China's boards. Corporate Ownership \& Control, 3, 142-147.

Wang, F., \& Xu, Y. (2004), What determines Chinese stock returns. Financial Analysts Journal, $60,65-77$.

Wei, Z., Xie, F., \& Zhang, S. (2005), Ownership structure and firm value in China's privatized firms: 1991-2001. Journal of Financial \& Quantitative Analysis, 40, 87-108.

Wu, Z., Li, Y., Ding, Y., \& Jia, C. (2009), Supervisory board and financial risk-taking: Behaviors in Chinese listed companies. In R.W. Kolb and D. Schwartz (Eds.), Corporate Boards: Managers of Risk, Sources of Risk, Wiley-Blackwell.

$\mathrm{Xi}, \mathrm{C}$. (2006), In search of an effective monitoring board model: Board reforms and the political economy of corporate law in China. Connecticut Journal of International Law, 22, 1-46.

Xiao, J., Dahya, J., \& Lin, Z. (2004), A grounded theory exposition of the role of the supervisory board in China. British Journal of Management, 15, 39-55.

Yueh, L. (2004), Wage reforms in China during the 1990s. Asian Economic Journal, 18, 149-164. 